\title{
HUBUNGAN POLA ASUH ORANG TUA DENGAN SELF ESTEEM REMAJA KELAS XI TKJ DI SMK DARUL FALAH SUNGAI TANANG NAGARI KASIK PUTIH KECAMATAN SUNGAI AUR KABUPATEN PASAMAN BARAT
}

\author{
${ }^{1}$ Khairul Amri, ${ }^{2}$ Sukatno, ${ }^{3}$ Ziska Haryanti \\ 1,2,3 Prodi Bimbingan dan Konseling, Universitas Muhammadiyah Tapanuli Selatan \\ khairul.amri@um-tapsel.ac.id
}

\begin{abstract}
This study aims to determine the relationship between parenting style and selfesteem of adolescent class XI TKJ at SMK Darul Falah Sungai Tanang Nagari Kasik Putih Sungai Aur District. This type of research is a descriptive study with a quantitative approach. The population in this study were all students of SMK Darul Falah Sungai Tanang consisting of 3 classes, namely class X, XI, and XII. The research sample consisted of 1 class, namely class XI TKJ totaling 26 students. The research instrument was a questionnaire of 30 questions. The data analysis technique used validity test, reliability test, normality test, linearity test, hypothesis test and multiple linear regression analysis.Based on the hypothesis test, the Sig. is equal to 0.000. Because the Sig. $0.000<0.05$, so according to the basis of decision making in the $F$ test it can be concluded that the hypothesis is accepted or in other words there is a significant positive relationship between parenting styles and self-esteem for adolescents in class XI TKJ at SMK Darul Falah Sungai Tanang.
\end{abstract}

Keywords: descriptive research, parenting style, self esteem

\begin{abstract}
Abstrak: Penelitian ini bertujuan mengetahui hubungan pola asuh orang tua dengan self esteem remaja kelas XI TKJ di SMK Darul Falah Sungai Tanang Nagari Kasik Putih Kecamatan Sungai Aur. Jenis penelitian ini adalah penelitian deskriptif dengan pendekatan kuantitatif. Populasi dalam penelitian ini adalah seluruh siswa SMK Darul Falah Sungai Tanang terdiri dari 3 kelas yaitu kelas X, XI, dan XII. Sampel penelitian terdiri dari 1 kelas yaitu kelas XI TKJ berjumlah 26 siswa. Instrument penelitian berupa kuisioner sebanyak 30 soal. Teknik analisis data menggunakan uji validitas, uji reliabilitas, uji normalitas, uji linearitas, uji hipotesis dan analisis regresi linier berganda.Berdasarkan uji hipotesis diketahui nilai Sig. adalah sebesar 0,000. Karena nilai Sig. 0,000 <0,05, maka sesuai dengan dasar pengambilan keputusan dalam uji $\mathrm{F}$ dapat disimpulkan bahwa hipotesis diterima atau dengan kata lain ada hubungan yang signifikan positif antara pola asuh orang tua dengan self esteem remaja kelas XI TKJ di SMK Darul Falah Sungai Tanang.
\end{abstract}

Kata kunci : penelitian deskriptif, pola asuh, self esteem

\section{PENDAHULUAN}

Masa remaja di deskripsikan sebagai masa transisi dari anak-anak menjadi dewasa dengan adanya interaksi antara faktor-faktor genetik, biologis, lingkungan dan sosial (Santrock, 2011: 402). Pada masa sebelumnya, yakni masa anak-anak, individu lebih sering menghabiskan waktu dengan orangtua untuk berbagi cerita tentang hal-hal yang dialami. Namun pada masa remaja, individu lebih sering menghabiskan waktu bersama teman-teman untuk berbagi cerita dibandingkan dengan 
orangtua. Selama periode ini, masyarakat secara relatif membiarkan remaja untuk bebas mencoba berbagai identitas, remaja dapat bereksperimen dengan berbagai peran terkait dengan tugas perkembangan baru yang dijalaninya. Misalnya,mencoba berbagai penampilan yang sesuai dengan teman kelompok sebayanya karena penampilan fisik dianggap penting oleh remaja untuk meningkatkan kepercayaan diri. Apabila remaja mampu menerima penampilan fisiknya maka remaja akan mengevaluasi diri secara positif. Hal tersebut juga dikarenakan adanya reaksi positif dari lingkungan sosialnya. Namun, jika remaja tidak mampu menerima penampilan fisiknya maka ia akan mengevaluasi diri secara negatif dan mengakibatkan remaja menjadi rendah diri (Hurlock, 1996: 197).

Evaluasi yang dilakukan oleh remaja mempengaruhi self esteem pada diri remaja. Self esteem adalah suatu evaluasi positif ataupun negatif terhadap diri sendiri. Self esteem adalah keseluruhan sikap seseorang terhadap dirinya sendiri baik secara positif atau negatif.

Oleh karena itu self esteem menjadi sangat penting bagi setiap individu karena self esteem yang baik akan berdampak positif pada lingkungan dengan penerimaan sosial terhadap dirinya, semakin positif harga diri yang dimiliki maka semakin ia merasa diterima dan menyatu dengan orang-orang di sekitarnya. Namun jika remaja tidak mampu memenuhi tugas perkembangannya dalam pembentukan jati dirinya, maka remaja cenderung memiliki self esteem yang rendah. Secara teoritis, individu yang mempunyai self esteem yang rendah cenderung mudah putus asa, tidak bersemangat dalam melakukan aktivitas, dan merasa bahwa dirinya tidak berguna. Self esteem yang rendah berhubungan dengan kondisi psikologis, fisik dan konsekuensi sosial yang dapat mempengaruhi kesuksesan perkembangan masa transisi anak ke usia remaja.

Pola asuh yang diterapkan orang tua mempunyai pengaruh cukup berarti bagi perkembangan anak sehingga pola asuh dapat dimengerti sebagai pola interaksi antara orang tua dan anak selama merawat dan mengasuh anak. jika pola asuh yang diberikan kepada anak secara otoriter dan orang tua selalu mengatakan supaya anak "bertindak sesuai dengan usianya", atau bahwa mereka harus menuruti kemauan orang tuanya untuk melanjutkan sekolah dimana yang sudah ditetapkan orang tua, kesalahan yang dilakukan orang tua dalam pola asuh seperti kurangnya pengawasan orang tua terhadap anak, orang tua yang tidak mendengarkan cerita anak dan orang tua yang terlalu asyik bekerja, maka mereka akan merasa inferior dan perasaan inilah yang mendorong penolakan diri.

Jadi dapat disimpulkan bahwa pola asuh orang tua sangat mempengaruhi self esteem remaja, bagaimana pola asuh orang tua di rumah akan berpengaruh pada kehidupan sosial anak baik di rumah, di lingkungan sekolah, serta lingkungan masyarakat. 
Berdasarkan fenomena yang saya Arikunto (2005:26) mengungkapkan bahwa temukan di SMK Darul Falah Sungai Tanang Nagari Kasik Putih Kecamatan Sungai Aur Kabupaten Pasaman Barat terdapat beberapa masalah siswa diantaranya : Siswa kurang mengenal dirinya sendiri dengan baik, masih adanya siswa yang tertidur di saat jam pelajaran, siswa cenderung segan mengambil resiko, suka menyendiri, susah berbaur dengan teman yang lainnya, kurang mampu menolak dan menyatakan ketidak setujuannya terhadap pendapat orang lain, siswa yang sering berkelahi, cabut disaat jam pelajaran, dan melawan terhadap guru. Kondisi ini terbawa sampai ke kelas yang lebih tinggi yang kemudian mempengaruhi minatnya untuk bersekolah. Dampaknya ada yang sampai malas ke sekolah.

Berdasarkan penjelasan di atas tampak bahwa selain teman, orangtua juga dapat mempengaruhi kondisi anak. Dalam hal ini, orang tua cenderung terlalu memaksakan keinginannya dan mengontrol perilaku anak. Kontrol orang tua yang berlebihan dapat berdampak buruk pada perkembangan self esteem remaja. Hal ini terjadi karena orangtua cenderung membatasi kebebasan yang dimiliki remaja, padahal remaja memiliki kebutuhan untuk mandiri dalam mengambil keputusan dan mewujudkan keinginannya.

\section{METODE}

Metode yang digunakan dalam penelitian ini adalah penelitian deskriptif dengan pendekatan kuantitatif yang bertujuan mengungkapkan sesuatu apa adanya. Menurut penelitian deskriptif tidak dimaksudkan untuk menguji hipotesis tertentu, tetapi hanya menggambarkan apa adanya tentang suatu variabel. Menurut Arikunto (2006 : 12) dengan penelitian kuantitatif, banyak dituntut menggunakan angka, mulai dari pengumpulan data penafsiran terhadap data tersebut, serta penampilan dari hasilnya. Populasi yang digunakan sebagai penelitian adalah Siswa Kelas X, XI, XII TKJ di SMK Darul Falah Sungai Tanang Nagari Kasik Putih Kecamatan Sungai Aur Kabupaten Pasaman Barat dengan jumlah populasi 72 siswa. Instrument yang digunakan dalam penelitian ini berupa angket atau kuisioner yang dibuat sendiri oleh peneliti

\section{HASIL}

Pola asuh merupakan sikap orang tua dalam berinteraksi dengan anak-anaknya. Sikap orang tua ini meliputi cara orang tua memberikan aturan-aturan, hadiah maupun hukuman, cara orang tua menunjukkan otoritasnya, dan cara orang tua memberikan perhatian serta tanggapan terhadap anaknya. Dari hasil pengujian hipotesis menggunakan bantuan SPSS 20 for windows, diketahui nilai Sig. adalah sebesar 0,000. Karena nilai Sig. $0,000<0,05$, maka sesuai dengan dasar pengambilan keputusan dalam uji $\mathrm{F}$ dapat disimpulkan bahwa hipotesis diterima atau dengan kata lain ada hubungan antara kecenderungan pola asuh orang tua dengan self esteem remaja kelas XI TKJ di SMK Darul Falah Sungai Tanang. 
Berdasarkan hasil interpretasi data Nagari Kasik Puth Kecamatan Sungai Aur menunjukkan bahwa, penelitian ini Kabupaten Pasaman Barat, dengan korelasi membuktikan antara pola asuh orang tua "cukup". dengan self esteem remaja kelas XI TKJ di SMK Darul Falah Sungai Tanang terdapat korelasi positif yang signifikan dengan kriteria korelasi cukup. Besar korelasi antara pola asuh orang tua dengan self esteem remaja diperoleh sebesar $55,3 \%$ sedangkan $44,7 \%$ merupakan besar korelasi dari faktor lain yang tidak diteliti dalam penelitian ini. Berdasarka hasil penelitian ynag dilakukan, dapat disimpulkan bahwa hasil perhitungan statistik dengan menggunakan analisis korelasi product moment membuktikan bahwa "terdapat hubungan positif yang signifikan antara pola asuh orang tua dengan self esteem remaja siswa kelas XI TKJ di SMK Derul Falah Sungai Tanang dengan korelasi cukup".

\section{SIMPULAN}

Berdasarkan hasil analisis dan pembahasan penelitian, maka kesimpulan dalam penelitian ini adalah ada hubungan signifikan yang positif antara pola asuh orang tua dengan self esteem remaja kelas XI TKJ di SMK Darul Falah Sungai Tanang. Berdasarkan hasil analisis di atas maka diperoleh nilai $\mathrm{r}_{\text {hitung }}$ adalah 0,553 sedangkan $r$ tabel taraf signifikan $0,05=0.388$, jadi nilai $r$ hitung lebih besar dari pada $r$ tabel yaitu $0,553>0,388$. Dengan demikian maka variabel $\mathrm{X}$ pola asuh orang tua dengan variabel $\mathrm{Y}$ self esteem remaja adalah signifikan artinya ada hubungan pola asuh orang tua dengan self esteem remaja kelas XI TKJ di SMK Darul Falah Sungai Tanang

\section{DAFTAR RUJUKAN}

Aco, H. (2020, Oktober). Siswa SMA Bunuh Diri Diduga Stres akibat Tugas Belajar Online. Retrieved from Trubunnews.com: https://www.tribunnews.com/regional/2 020/10/17/siswa-sma-bunuh-dirididuga-stres-akibat-tugas-belajaronline?page $=220$ Oktober 2020.

Azwar, S. (2016). Reliabilitas dan Validitas Edisi 4. Yogyakarta: Pustaka Pelajar.

Barseli, M., Ifdil, \& Nikmarijal. (2017). Konsep Stres Akademik Siswa. Jurnal Konseling dan Pendidikan, 143-148.

Gibson, J., Ivancevich, J. M., \& Donnelly, J. H. (1996). Organisasi: Perilaku, Struktur, Proses. Jilid 1 Edisi 8. Jakarta: Binarupa Aksara.

IKAPI. (2004). Manajemen Stress Cetakan I. Jakarta: Penerbit Buku Kedokteran.

Looker, T., \& Gregson, O. (2005). Managing Stress: Mengatasi Stres secara Mandiri Cetakan I. Yogyakarta: BACA.

Oktavia, W. K., Fitroh, R., Wulandari, H., \& Feliana, F. (2019). Faktor-faktor yang Mempengaruhi Stres Akademik. Prosiding Seminas Nasional Magister Psikologi Universitas Ahmad Dahlan, 142-149.

Primasiwi, A. (2020, Juni 26). Pembelajaran Jarak Jauh perlu Dievaluasi Pemerintah, Pastikan Efektivitasnya. Retrieved from Suaramerdeka 27 Oktober 2020 https://www.suaramerdeka.com/news/n asional/232585-pembelajaran-jarakjauh-perlu-dievaluasi-pemerintahpastikan-efektivitasnya 
Reddy, K. J., Kharismarajanmenon, M., \& Anjanathattil. (2018). Academic Stress and its Sources among University Students. Biomedical \& Pharmacology Journal, 11(1), 531-537.

Sudarsana, D. (2019). Pengaruh antara Stres Akademik dengan Prestasi Belajar Siswa Kelas IX SMPN 2 Kemalang . Jurnal Riset Mahasiswa Bimbingan dan Konseling, 204-207. 